\title{
Critical Point of View: The Challenges of Agricultural Sector on Governance and Food Security in Indonesia
}

\author{
Lilies Setiartiti ${ }^{1, *}$ \\ ${ }^{1}$ Department of Economics, Universitas Muhammadiyah Yogyakarta, Indonesia
}

\begin{abstract}
This critical review evaluates the agriculture sector's challenges by assessing the agriculture sector related to government food security policies. The agriculture sector faces many problems, including during 2019 it only grew by $3.08 \%$ than the previous year, as the second GDP contributor, although it has the potential to reduce unemployment, it has not been supported by adequate human resources and even tends to degeneration due to the lowest income compared to others. Another serious problem is that every year, there is a reduction of between 150,000 to 200,000 hectares of land due to conversion of function for infrastructure development. As an agrarian country, Indonesian farmers' welfare has also not changed much from year to year. Farmers Exchange Rate (NTP) in 2019 was 104.46 , only growing $1.25 \%$ from the previous year. The low wages of agricultural laborers, limited land ownership, agricultural products' selling price do not benefit the farmers, making their welfare still low. With this phenomenon, Indonesia urgently needs to reform its governance in the agricultural sector, and restore BULOG's role. Strengthening the Bulog's role will be able to maintain food price stability and motivate farmers' interest to continue planting rice and various other food commodities.
\end{abstract}

\section{Introduction}

Food is the most crucial basic human need and basic right for everyone. Therefore, food needs are necessary so that humans can survive [1]. All human beings, without exception, have the right to enjoy and get a source of livelihood from the womb of the earth, especially food, which is the basic necessity of human life [2]. To keep and maintain its quality and function, the earth's management and cultivation are directed to preserve its existence in a dynamic balance through continuous protection and rehabilitation efforts. Thus, the earth and its contents can be utilized for the maximum welfare of life together with all humankind from one generation to the next, $[3,4,5]$.

Food is closely related to human survival in all parts of the world. Lack of sufficient food availability for human needs in a country will decrease people's welfare level, cause various diseases, famine, and even have the potential to cause a bigger disaster [6]. Longing for reliable food management, it is impossible without efforts to build food independence

${ }^{*}$ Corresponding author: setiartiti.lilies1267@gmail.com 
and sovereignty, which is a strategic effort to prevent food crises and prevent people from poverty, especially the farmer community. The importance of food independence and sovereignty has become a united concept, where its availability is continuous, its distribution is evenly distributed throughout society, the price is affordable by the the community's purchasing power, and its production is profitable for farmers with wellplanned and well-managed management [7].

Foods, covers a wide dimension, not only rice. Many local food in Indonesia are of the same quality as rice. There are corn and sago, ten thousand tubers grow widely in all corners of the country [22]. Considering that food is a basic need and human right, it is necessary to involve the people in determining food governance policies related to food production, distribution and consumption. The problem of production implies that the state must guarantee an adequate amount of food for its people, distribution is related to food availability at any time and is evenly distributed throughout the territory of the state, while consumption is related to food that must be safe for consumption and guaranteed quality [2]. Meanwhile, problems related to food and Indonesian farmers' fate have been clearly identified for a long time. A number of government food policies, including protecting the fate of farmer-fishermen, have also become laws. However, the reality in the field revealed that what always recurred is the fluctuation of food prices. The farmers' welfare has not improved, placing them as a group that only received a small slice of the development cake $[8,9]$.

Food governance does show results when food inflation continues to decline. BPS data uncovered that food inflation decreased from 2015 to 2019 by $67.74 \%$, from $10.57 \%$ (2015) to $3.41 \%$ (2018). This result occurred because the Indonesian economy from 2015 to 2019 did not grow, or was stagnant at the $5 \%$ level every year (BPS, 2019). This economic stagnation also indicates that national production has not increased, including in the agricultural sector. At the other hand, in the 2018 period the agricultural sector only grew by $3.91 \%$ with a contribution of $12,81 \%$ to GDP [10]. It was the third contributor after the manufacturing and wholesale and retail sectors, which respectively contributed $19.62 \%$ and $13.02 \%$ to GDP. Even food crops' contribution was only $3.03 \%$ of the GDP [10]. This condition confirms that as an agricultural country, the agricultural sector is no longer a leading sector in the Indonesian economy. It impact the farmers' fate, which has not changed much from year to year. It is reflected in farmer welfare indicators, namely the Farmers Exchange Rate (NTP) index which tends to move flat. Data from the Central Bureau of Statistics recorded that NTP in August 2018 was at the level of 102.56, meaning that it fell $0.49 \%$ from the position at the end of 2017 . This condition confirms that the farmers' purchasing power (welfare) throughout 2019 fell $0.49 \%$.

As one of the staple food commodities that has a strong influence on the economy, especially in its contribution to national inflation, rice availability and affordability must be maintained for the community so that price control policies become the main element $[1$, 11]. With regard to food, the current trade liberalization has changed the multi-dimensional function of food into merely a trading commodity. Even the WTO defines food security as "food availability in the market" [12]. In practice, this concept forces people in developing countries like, Indonesia, to fulfill food need will be fulfilled by developed countries through free market mechanisms [9]. This fact shows that food has become part of the grand scheme of trade liberalization. With these conditions, domestic food prices will be greatly influenced by the global food market [12].

With this phenomenon, Indonesia really needs to make improvements in food management. Improvements need to be made to the national food import trade system, especially concerning production, distribution and consumption [4]. It includes the food data issues, which so far have often been highlighted by various parties. The gap between regulations and implementation in the field is one of the causes of tearing up food 
management. The implementation of existing rules in the field is intertwined with various business and political interests. One example is the chaotic food data. One state institution with another is out of sync with this data. This chaotic data issue is reflected when one ministry and another ministry argue with each other regarding food production [13].

Regarding the building of food governance in Indonesia, the authors highlight the upstream side, namely the agricultural sector's role as a whole in the national economy, and its impact on the farmers' welfare level. For the author, looking at the upstream sector is very urgent considering how to build good food governance will support the food sustainability.

\section{Methodology}

The methodology used in this study was to conduct a critical analysis of the various challenges and problems faced by the agricultural sector, particularly in the upstream areas. Examining the agricultural sector upstream for Indonesia is vital because the sustainability of governance and food security is strongly influenced by the upstream areas' performance. Good sector performance will encourage good governance and food security system, and vice versa.

\section{Result and Discussions}

\subsection{The role of the agricultural sector in Indonesia economy}

Indonesia is a country with fertile land, rich in natural resources, and has high potential in developing agricultural businesses. Moreover, it is only right for society to cultivate every abundance of available resources to the maximum extent possible by utilizing the agricultural sector. The agricultural sector is a sector that still has vital role in the national economy structure [6]. Several reasons that underlie the importance of agriculture in Indonesia: (1) its large and varied resource potential, (2) a relatively large share of national income, (3) the large number of the population who depend on this sector for life, namely $50 \%$ of the population [10], and (4) become the basis of economic growth in rural areas. Besides, tropical agriculture, which is a promising sector, sees the potential of Indonesia's vast natural resources. Figure 1 below illustrates that the agricultural sector absorb the largest number of workers, $28.79 \%$ of Indonesia's total workforce in 2019 . The second position was the trade sector, and the industrial sector was the third largest sector in the labor absorption. With the immense potential for this labor absorption, the agricultural sector should be the solution to the problem of alleviating unemployment, because this sector cannot significantly be replaced by the presence of modern technology today [5].

The agricultural sector is the primary sector that plays an essential role in the national economy in absorbing labor, a source of economic growth, and a contributor to foreign exchange. Besides, the agricultural sector also drives other sectors in the national economy. Starting from this condition, attention to the availability of complete, accurate, and up-todate agricultural sector data is needed as a reference for the government and stakeholders in planning and policy formulation [8]. As an agricultural country, the agricultural sector is crucial in the forming added value to the national economy because $60 \%$ of Indonesia's population is in rural areas where agricultural activities are their livelihood, and food is a strategic commodity for human survival [14]. Thus, the agricultural sector should be a cornerstone of economic sovereignty and independence for Indonesia. As the backbone of the economy, the agricultural sector should have received full attention from the government for its sustainability in the future. Agricultural activities do not only include the 
activity of planting agricultural commodity crops, but activities that are backward and forward linkage $[7,14]$.

\section{Employee Profile by Sector (\%)}

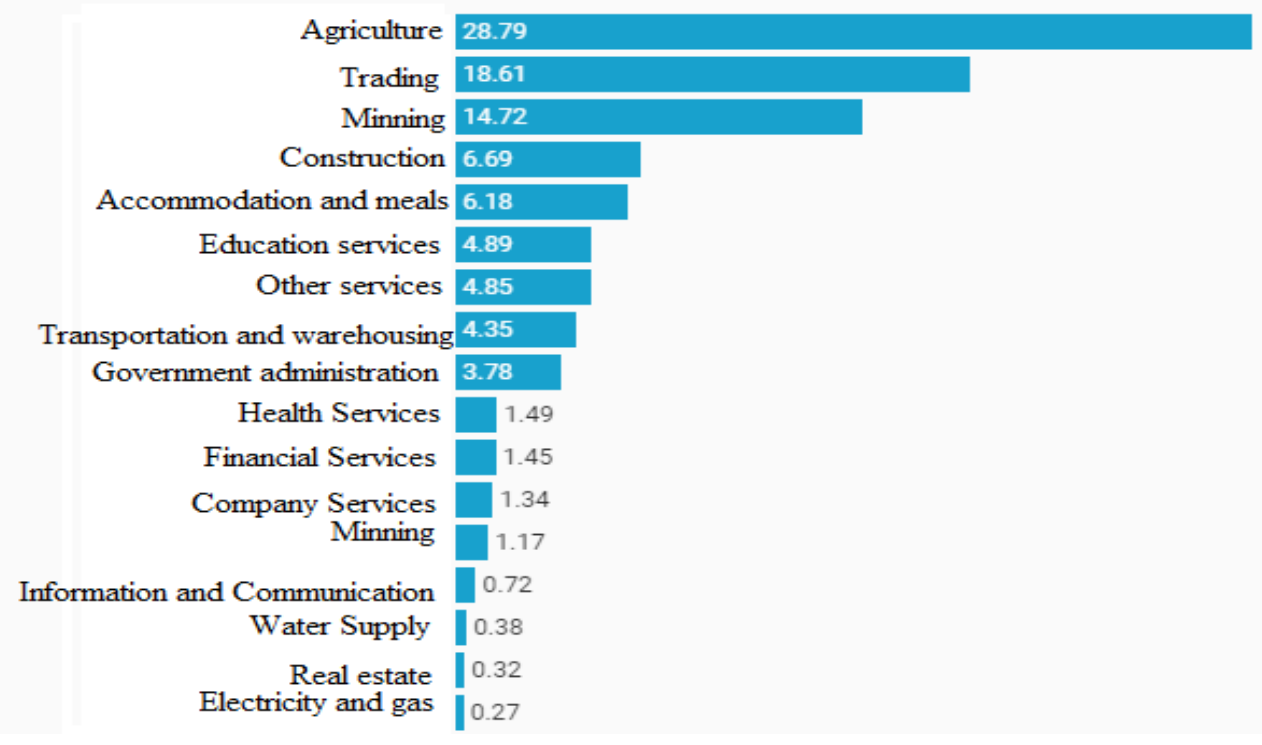

Source: [10]

Fig. 1. Employee Profile by Sector (\%), 2019

Production in the agricultural sector is also as an input for agro-industrial development Over the past three years, from 2016 to 2018, the agricultural sector has still shown GDP performance, although its contribution has always decreased every year. Despite positive growth, in 2018, the agricultural sector was only the third contributor after the Manufacturing Industry sector, and the wholesale and retail trade sector, with a contribution of $12.81 \%$ [10]. This condition can be caused by various factors, such as natural factors, harvested area, technology use, and inadequate infrastructure. The decline in the agricultural sector's share is likely will continue in the coming years, in line with the increasing conversion of land functions due to seeking economic rent, becoming industrial areas, property, and housing [16]. The following Table 1.confirms the agricultural sector's performance for the last three (3) years.

From the table above, it can be seen that during the 2018 period, even though growth increased compared to the previous year period, the agricultural sector could only become the third contributor, after the manufacturing sector and the wholesale and retail trade sector, which each contributed $19.86 \%$ and $13.02 \%$ of GDP. This decline needs attention because this sector absorbed the most labor, which was 38.7 million people or $30.46 \%$ of the total Indonesia's workforce [10]. Hence, its performance is expected to reduce the open unemployment rate which was still relatively high in Indonesia, as many as 5.13\% [10]. The agricultural sector is also lower than that of other sectors, especially the tertiary sector, which had a relatively lower employment potential. The decline in the agricultural sector's contribution to GDP, was also due to land-use changes, with an average of 150,000200,000 hectares per year [8]. 
Table 1. Growth and Distribution Rate by Sector 2016-2018 (\%)

\begin{tabular}{|c|c|c|c|c|c|c|c|}
\hline \multirow[t]{2}{*}{ No } & \multirow[t]{2}{*}{ Economic Sector } & \multicolumn{3}{|c|}{$\begin{array}{c}\text { Growth rate } \\
\text { at constant prices }\end{array}$} & \multicolumn{3}{|c|}{$\begin{array}{r}\text { Share based on } \\
\text { current prices }\end{array}$} \\
\hline & & 2016 & 2017 & 2018 & 2016 & 2017 & 2018 \\
\hline $\mathbf{A}$ & Agriculture, forestry, fishing & 3.37 & 3.87 & 3.91 & 13.48 & 13.15 & 12.81 \\
\hline $\mathbf{B}$ & Mining and quarrying & 0.95 & 0.66 & 2.19 & 7.19 & 7.58 & 8.08 \\
\hline $\mathbf{C}$ & Manufacturing & 4.26 & 4.29 & 4.27 & 20.52 & 20.16 & 19.86 \\
\hline D & Electricity and Gas & 5.39 & 1.54 & 5.47 & 1.15 & 1.19 & 1.19 \\
\hline $\mathbf{E}$ & $\begin{array}{l}\text { Water,processing of waste, waste and } \\
\text { recycling }\end{array}$ & 3.60 & 4.60 & 5.46 & 0.07 & 0.07 & 0.07 \\
\hline $\mathbf{F}$ & Construction & 5.22 & 6.80 & 6.09 & 10.38 & 10.38 & 10.53 \\
\hline G & $\begin{array}{l}\text { Wholesale and retail, car and } \\
\text { motorcycle repair }\end{array}$ & 4.03 & 4.46 & 4.97 & 13.19 & 13.02 & 13.02 \\
\hline H & Transportation and sotage & 4.75 & 8.49 & 7.01 & 5.20 & 5.41 & 5.37 \\
\hline I & $\begin{array}{l}\text { Accommodation and Food Service } \\
\text { Activities }\end{array}$ & 5.17 & 5.39 & 5.66 & 2.93 & 2.85 & 2.78 \\
\hline $\mathbf{J}$ & Information and Communication & 8.88 & 9.63 & 7.04 & 3.62 & 3.78 & 3.77 \\
\hline $\mathbf{K}$ & Financial and Insurance Activities & 8.93 & 5.47 & 4.17 & 4.19 & 4.20 & 4.15 \\
\hline $\mathbf{L}$ & Real Estate & 4.69 & 3.66 & 3.58 & 2.83 & 2.81 & 2.74 \\
\hline $\mathbf{M}, \mathbf{N}$ & Business Activities & 7.36 & 8.44 & 8.64 & 1.71 & 1.75 & 1.80 \\
\hline $\mathbf{O}$ & $\begin{array}{l}\text { Public Administration and Defence; } \\
\text { Compulsory Social Security }\end{array}$ & 3.20 & 2.06 & 7.02 & 3.84 & 3.67 & 3.65 \\
\hline $\mathbf{P}$ & Education & 3.84 & 3.70 & 5.36 & 3,37 & 3.28 & 3.25 \\
\hline $\mathbf{Q}$ & $\begin{array}{l}\text { Human Health and Social Work } \\
\text { Activities }\end{array}$ & 5.16 & 6.84 & 7.13 & 1.07 & 1.06 & 1.06 \\
\hline R,S,T,U & Other Services Activities & 8.01 & 8.73 & 8.99 & 1.70 & 1.76 & 1.81 \\
\hline & GDP & 5.03 & 5.07 & 5.17 & 100 & 100 & 100 \\
\hline
\end{tabular}

Source: [10]

With a competitive market structure, the agricultural sector has the greatest potential for employment in Indonesia. Nevertheless, agricultural sector's high absorption capacity is not followed by government's maximum efforts to build up the sector. Farmers and the agricultural sector are still placed in a marginal position. Government policies tend to conflict with the famer's wishes. As shown by the import policy for rice, sugar, and other commodities, it reflects the contradiction between farmers' and the government's wishes. This condition makes the famer's fate not getting better [14]. Moreover, although the agricultural sector dominates in labor absorption and has the potential to reduce unemployment rates, it is not supported by adequate human resources and even tends to decline in interest (degeneration) due to less promising agricultural income and low social status [6]. The condition of human resources in agriculture or farmers in Indonesia is still very low. Judging from their education, $59,2 \%$ of farmers did not complete elementary school, and $32.1 \%$, graduated from junior high school and senior high school, respectively $5.7 \%$ and $2.9 \%[8]$.

Labor wages in the agricultural sector were also the second-lowest wages than workers in other sectors, namely only IDR 1.76 million per month [10]. This condition discourages youth from working in agriculture. This condition impacts farming activities sustainability. The lack of youth working in agriculture is because the level of wages in this sector is the lowest compared to other sectors, so that the majority of those working in agriculture are elderly farmers, making it difficult to race an increase in production [1]. Workers in agriculture were dominated by the age group above 55 years [8]. 
Table 2. Average Monthly Wages of Workers by Main Employment in 17 Categories and Gender (Rupiah), February 2018

\begin{tabular}{|c|c|c|c|c|}
\hline No & Economic Sector & Male & Female & $\begin{array}{l}\text { Average of Male } \\
+ \text { Female }\end{array}$ \\
\hline $\mathbf{A}$ & Agriculture, forestry, fishing & $1,919,281$ & $1,173,189$ & $1,761,849$ \\
\hline B & Mining and quarrying & $4,166,476$ & $3,432,486$ & $4,127,345$ \\
\hline $\mathrm{C}$ & Manufacturing & $2,774,160$ & $1,982,102$ & $2,478,866$ \\
\hline D & Electricity and Gas & $3,418,728$ & $3,389,996$ & $3,416,517$ \\
\hline $\mathbf{E}$ & $\begin{array}{l}\text { Water,processing of waste, waste and } \\
\text { recycling }\end{array}$ & $3,300,050$ & $1,544,872$ & $2,892,345$ \\
\hline $\mathbf{F}$ & Construction & $2,617,644$ & $2,914,710$ & $2,628,165$ \\
\hline G & $\begin{array}{l}\text { Wholesale and retail, car and } \\
\text { motorcycle repair }\end{array}$ & $2,288,125$ & $1,898,599$ & $2,160,642$ \\
\hline $\mathbf{H}$ & Transportation and storage & $3,123,902$ & $3,798,340$ & $3,172,077$ \\
\hline $\mathbf{I}$ & $\begin{array}{l}\text { Accommodation and Food Service } \\
\text { Activities }\end{array}$ & $2,428,468$ & $1,675,318$ & $2,098,481$ \\
\hline $\mathbf{J}$ & Information and Communication & $4,095,985$ & $3,971,476$ & $4,059,364$ \\
\hline $\mathbf{K}$ & Financial and Insurance Activities & $4,207,564$ & $3,986,938$ & $4,134,866$ \\
\hline $\mathbf{L}$ & Real Estate & $3,038,086$ & $3,206,435$ & $3,073,709$ \\
\hline $\mathbf{M}, \mathbf{N}$ & Business Activities & $3,219,021$ & $2,803,977$ & $3,127,060$ \\
\hline $\mathbf{O}$ & $\begin{array}{l}\text { Public Administration and Defence; } \\
\text { Compulsory Social Security }\end{array}$ & $4,039,256$ & $3,230,805$ & $3,808,741$ \\
\hline $\mathbf{P}$ & Education & $3,014,153$ & $2,510,787$ & $2,710,224$ \\
\hline $\mathbf{Q}$ & $\begin{array}{l}\text { Human Health and Social Work } \\
\text { Activities }\end{array}$ & $3,252,513$ & $2,841,962$ & $2,968,612$ \\
\hline $\mathbf{R , S , T , U}$ & Other Services Activities & $1,997,8115$ & $1,155,816$ & $1,435,939$ \\
\hline \multicolumn{2}{|r|}{ Average National Labor Wage } & $2,910,301$ & $2,213,262$ & $2,654,070$ \\
\hline
\end{tabular}

Source: Indonesian Labor Statistics, 2018

Besides the regeneration problem and low wages levels, another problem is the agriculture land conversion in Indonesia. After constructing roads and being utilized, new economic growth poles began in the vicinity, such as factories and housing, thereby reducing rice fields. In fact, rice fields are an essential instrument in supporting national food security. Records revealed that in 2018 , there were only 7.1 million hectares of rice fields left, down compared to 2017 which was still 7.74 million hectares, and every year there was a reduction of between 150,000 and 200,000 hectares due to land conversion [10]. The government's efforts to produce new rice fields could only to produce around 60,000 hectares of rice fields each year. Thus, the rice field deficit was around 350,000 hectares over the last five years [8]. The change in rice fields' function has caused a high potential for food loss each year due to reduced planting areas [17]. This condition strengthens Malthus's opinion that population growth is much faster than food growth. As a result, Indonesia in the future will experience food shortages in line with rapid population growth, and the solution that must be done is to increase the number of food imports. In the long run, it will disrupt food sovereignty and national sovereignty because of the increasing dependence on other countries [18].

\subsection{Rice production and consumption}

Food production is the most complicated sector in food management in Indonesia. Yields depend not only on land area and planting period but also on weather and pests [19]. The use of production factors and the application of technology plays an essential role. The use of production factors and the application of inaccurate technology will result in low production and high farming costs [20]. Post-harvest technology must have touched our 
farmers. Without post-harvest management, farmers have the potential to lose up to $10 \%$ of their agricultural produce [13]. During the last five (5) years, Indonesian rice production has always increased as well as the harvest area. In 2018, rice production reached 83 million tons, an increase of $2.47 \%$ from the previous year which reached 81 million tons. The growth in rice production from 2016 to 2018 on average only grew by $2.3 \%$ per year, whereas in the previous period it grew by $5.84 \%$ [8].

The national rice production for the 2018 period was still in surplus until September, but in the fourth quarter, production continued to decline, and at the end of 2018 there was a deficit of 3.51 million tons [8]. To cover this deficit, the government had to import from other countries, especially from Thailand, China, and Vietnam [20]. Even so, there were still inefficiencies in Indonesia's rice imports. It occured because the rice consumption per capita in Indonesia is $130 \mathrm{~kg} /$ year. This data should be more detailed per age not averaged, because rice consumption between toddlers, children and adults is certainly not the same. Therefore, Indonesia must have accurate rice needs data, so the estimated annual rice needs can be predicted correctly. Another fact showed that national rice production costs were also inefficient, and the highest than rice producing countries in Asia, even twice the Vietnam production cost. The high cost of rice production in Indonesia was due to the high cost of renting land cost and labor cost. Table 3 below, displays the condition.

Table 3. Rice production costs, land rent, and labor costs in several Asian rice producing countries

\begin{tabular}{|c|l|c|c|c|c|c|}
\hline No & Country & $\begin{array}{c}\text { Production Cost } \\
\text { Per Kg (IDR) }\end{array}$ & $\begin{array}{c}\text { Land Rental } \\
\text { Cost per Kg } \\
\text { (IDR) }\end{array}$ & $\begin{array}{c}\text { \% of Cost } \\
\text { Production }\end{array}$ & $\begin{array}{c}\text { Labor Cost } \\
\text { per Kg } \\
\text { (IDR) }\end{array}$ & $\begin{array}{c}\text { \% of Cost } \\
\text { Production }\end{array}$ \\
\hline 1 & Indonesia & 4,079 & 1,719 & 42.14 & 1,115 & 27.33 \\
\hline 2 & Tiongkok & 3,661 & 988 & 27.0 & 126 & 3.44 \\
\hline 3 & Philippines & 3,224 & 549 & 17.03 & 978 & 30.33 \\
\hline 4 & India & 2,306 & 510 & 22.17 & 655 & 28.40 \\
\hline 5 & Thailand & 2,301 & 481 & 21.0 & 172 & 7.47 \\
\hline 6 & Vietnam & 1,696 & 387 & 22.64 & 120 & 7.07 \\
\hline
\end{tabular}

Source: [10]

\subsection{Farmer welfare}

Farmers Exchange Rate (NTP) is an indicator to see the level of famers' capacity/purchasing power in rural areas. This indicator is obtained from the comparison between the Price Index Received by Farmers (IT) and the Price Index Paid by Farmers (IB) expressed as a percentage. NTP also shows the term of trade between farmers' agriculture product with goods and services needed by farmers in production and household consumption. By comparing the two developments in these numbers, it can be seen whether the increase in expenditure for farmers' needs can be compensated by the increase in farmers' income from their agricultural products. The higher the NTP value, the relatively higher the capacity or purchasing power of farmers [10].

Indonesia is an agricultural country where most of its people live in the agricultural sector. However, it seems that the farmers' fate in the country has not changed much from year to year [19]. It was reflected in the farmer welfare indicator, where the Farmers Exchange Rate (NTP) index tends to move up slightly as shown in the Table 4.below. The welfare indicators for farmers during 2018 were still concerning, even though they have increased quite slightly. It was exhibited in the monthly farmer exchange rate (NTP), which only rose $0.04 \%$ to 103.17 in December compared to the previous month. As a result, the annual NTP only increased by $0.59 \%$ from the position at the end of 2017 at 103.07 , and to 103.88 at the end of 2019 , or grew by $0.63 \%$. The increase in NTP was supported by the increase in the price index received by farmers (IT) in December last year by $0.54 \%$ to 
138.16 from the previous month. Meanwhile, the price index paid by farmers (1B) only rose $0.50 \%$ to 133.93 from the previous month [10].

Table 4.below, confirms that farmers' welfare level in Indonesia during the last five years has not been satisfactory because the index was only slightly above the minimum value of 100 , with a growth rate that was also still below $1 \%$ during the five year. The low welfare rate of Indonesian farmers can cause the agricultural sector's contribution to declining over the past three years because the opportunity cost of leaving farming activities is lower than if the farmers remained in agricultural activities.

Table 4. Indonesian Farmers Exchange Rate

\begin{tabular}{|c|c|c|c|c|c|}
\hline \multirow{2}{*}{ No } & \multicolumn{5}{|c|}{ Farmers Exchange Rate (NTP) } \\
\cline { 2 - 6 } & $\mathbf{2 0 1 5}$ & $\mathbf{2 0 1 6}$ & $\mathbf{2 0 1 7}$ & $\mathbf{2 0 1 8}$ & $\mathbf{2 0 1 9}$ \\
\hline 1 & 102,33 & 102,02 & 102,22 & 103,17 & 104,46 \\
\hline & \multicolumn{5}{|c|}{ Growth (\%) } \\
\hline 2 & 1,04 & 0,45 & 0,61 & 0,59 & 1,25 \\
\hline
\end{tabular}

Source: [10]

The low wages of agriculture laborers, the lack of land they own, and the selling price of agricultural products that do not benefit farmers, have made farmer welfare indicators not yet improving. Although food prices often increase, such as during the fasting month and Eid, it does not impact on farmers because the ones who get big profits are speculators and not the farmers [20].

Based on the research I conducted in Yogyakarta, the biggest gross margin for agricultural commodities was obtained by intermediaries. For rice commodities, the gross margin obtained by intermediaries was quite large, namely $76 \%$. It occurs because, in general, the determination of prices for agricultural commodities is through market mechanisms, however, at the middleman level, intermediaries have a bigger role in price creation. The domination of price margins at the middleman/wholesaler level is caused by many factors: bearing greater transportation costs, and bearing business risks due to very vulnerable product character in terms time/not last long. Besides, the market structure is a competitive market. It is based on the characteristics of the number of producers, intermediaries/wholesalers, and the number of traders, all of whom are large in quantities. In addition, the nature of agricultural business is relatively open, and not controlled by the government [15].

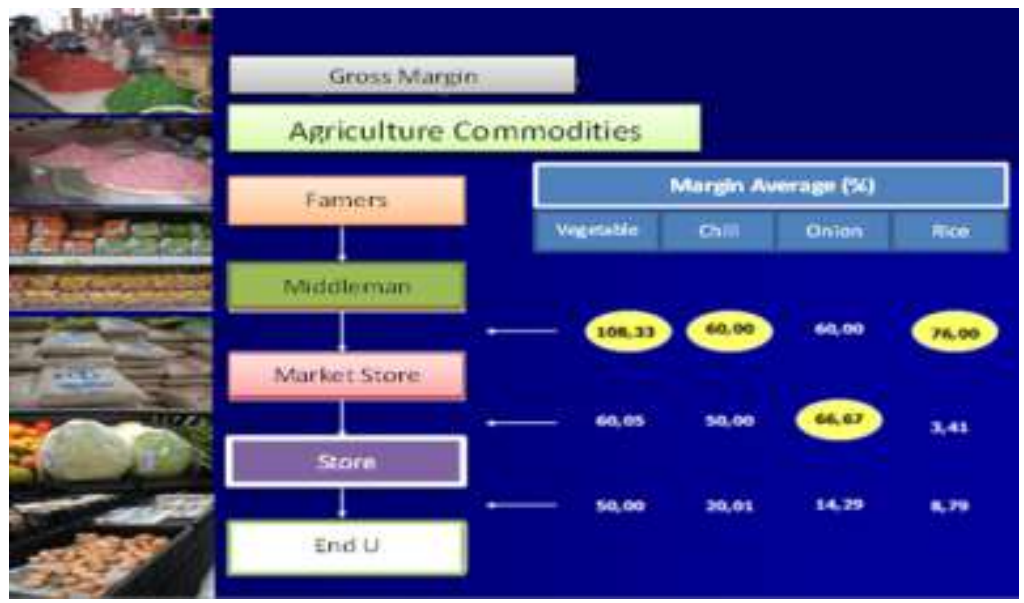

Source: [15]

Fig. 3. Gross Margin of Agricultural Commodity 


\subsection{The importance of bulog's role in national food governance}

The Logistics Agency (Bulog) is the only non-departmental government agency (LPND) that acts as a supporting agency for basic necessities including rice. Its main task is to stabilize the prices of 7 (seven) basic commodities, including: rice, sugar, beef, chicken meat, flour, chicken eggs and soybeans. Bulog's assignment is stated in the Presidential Decree No. 50/1995. The results proved that the effectiveness of producer price control and price stability among consumers was very good and maintained until 1998, before the monetary crisis occurred in May 1998. The community felt calm with the stable prices of basic food need in the market. The success of Bulog in the New Order era could not be separated from the governance and management of Bulog institutions [13]. During the New Order era, although in line with the coordination of Bulog under the Ministry of State Secretariat, its duties and responsibilities were directly to the President. It prompted the rice self-sufficiency program to be realized during the New Order era in the mid-1980s due to the President's direct attention. Unfortunately, after the 1998 monetary crisis passed, what was the role of Bulog? Why does Bulog seem unable to dominate the food commodity market (especially rice) at this time? This question has not been wholly answered up to now [19].

The role of Bulog has shifted after the monetary crisis in 1998. The change in Bulog's role and authority is in line with the political changes of most BUMNs which are the implications of the agreement in the Letter of Intent (LoI) between the Indonesian government and the International Monetary Fund (IMF). Besides, it is also an implication of Law No.19/2003 about BUMN. It means that Bulog, which initially played a role as a food buffer with an emphasis on stabilizing food prices, become a profit-oriented institution, even though Bulog is already a state enterprise in the form of a public company or PERUM [16]. Although BUMN is a public company, it should not only seek profit, but also must providing public goods needed by many people, such as rice. The role in balancing and stabilizing food prices in the market has already been lost. The role of Bulog is the same as other companies whose primary emphasis is on profits which are indicators of the success of business performance [19].

Of course, returning the role of Bulog to its original role by improving or revitalizing its duties and functions of course, is urgently needed in Indonesia's food governance policy right now. Strengthening the role and function of Bulog will be able to maintain food price stability and motivate farmers' interest to continue planting rice and various other food commodities. Restoring Bulog's function as a buffer means giving the flexibility to buy all the food produced by farmers and distribute it to areas, which are not as rice production centers such as Eastern Indonesia and other archipelagic areas [16] (Vinita,2014, Degia,2016,). It also applies, for example, to other commodities. Thus, Bulog is expected to be able to fulfill all elements, both producers and consumers. Bulog needs to set a government purchase price (HPP) to provide incentives to farmers in increasing food production, so that people can access the rice at an affordable price [21]. The purchase of rice by Bulog at a price set by the government can be used by for various purposes, especially for people's welfare at affordable rice prices. In order that food price turbulence on world markets does not directly affect domestic food prices, it is necessary to establish price relations with world markets with wide fluctuations.

Bulog should also have sufficient buffer stocks. Because without sufficient buffer stocks, the government cannot intervene in the market to stabilize prices during food price fluctuations in the market. Through the stabilization of food prices directly under the President, Bulog should be able to manage food with more modern management while still adhering to the principles of good governance [21]. The following is an example of government intervention through Bulog on setting the lowest retail price (floor price) and the highest retail (ceiling price) on food commodities. 


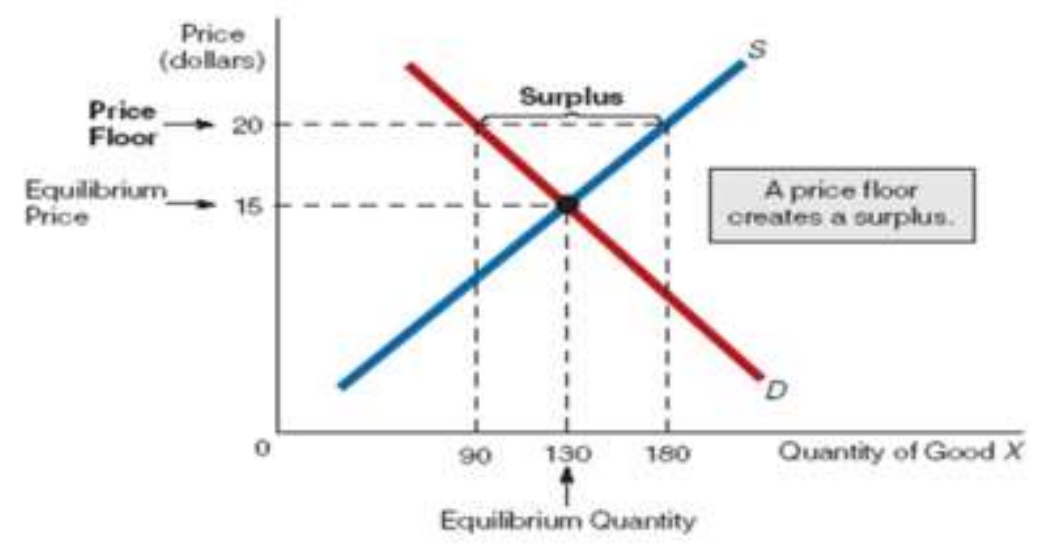

Fig. 4. Floor Price Policy

The government determines the minimum price to protect farmers so that at harvest time they can sell/obtain a minimum price according to the HPP, so that in running their business farmers still get a fair profit. If the market price is higher than HPP, farmers are allowed to sell to the market and there is no obligation for them to sell to BULOG. It lets the farmer enjoy a good price. However, if the price of rice falls at the same time as or below the HPP, it is BULOG's obligation to absorb the farmers' crops, so that the farmers are protected. Thus, the HPP is actually a price protection instrument.

Meanwhile, the government's determination of maximum price aims to protect consumers, where the price is the highest allowed change in the price of a good that has been determined in a policy. The market price, which is affected by this price, is not allowed to increase the price above the predetermined maximum price. This policy is usually carried out when there is a dry season, where the supply of goods is less than community's needs or the market.

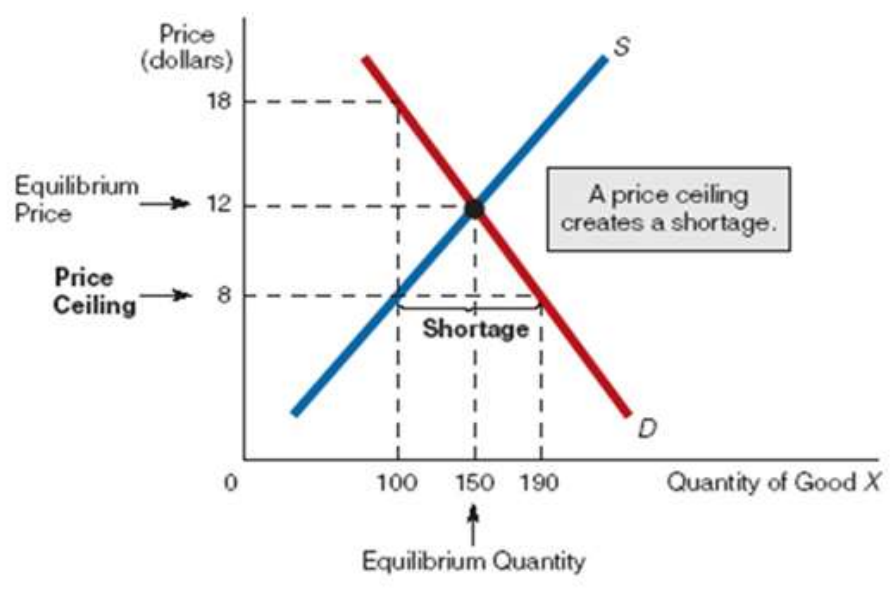

Fig. 5. Ceiling Price Policy

In this highest price policy, the determined price is lower than the market price, so there will be excess demand. To meet this excess demand, the government through Bulog can increase the supply of goods through market operations, or it can also be done by using the coupon method. 


\section{Conclusion}

Problems related to food and Indonesian farmers' fate have been clearly identified for a long time. Many government policies regulating food, including protecting farmers' fate, have been made. However, the farmer's welfare has not improved relatively yet, placing them as a group that only gets a small slice of the development cake. Even though as an agricultural country, farmers in Indonesia should be the party who enjoys the highest income compared to other sectors. A latent problem in the food sector that cannot be avoided is conversion rate of agricultural land functions, which is quite large every year. It is what makes the national average of 0.3 hectares of famers'land ownership unchanged.

High prices for agricultural commodities are not due to limited production but because of distribution constraints. The role of the speculator is also very significant in the case of a number of agricultural commodities. Speculators not only want profits from the price difference but also want to make profits from imported foodstuffs. Inaccurate production data and distribution channels have increasingly overwhelmed the government in overcoming food distribution problems. With these conditions, we must admit that currently Indonesia is only at the stage of food security, has not yet reached the phase of food self-sufficiency, as achieved by this nation in 1984. Therefore, food management is very strategic to be addressed so that various efforts are made. It must be done by the government to ensure the availability and distribution of basic foodstuffs for all people.

\section{Reference}

1. J. J. L. Candel, NJAS - Wageningen J. Life Sci. 84, 103 (2018).

2. K. Boratyńska és R. T. Huseynov, J. Innov. Knowl. 2, 39 (2017).

3. E. Lukášková, K. Pitrová, P. Taraba, és H. Velichová, Proc. 26th Int. Bus. Inf. Manag. Assoc. Conf. - Innov. Manag. Sustain. Econ. Compet. Advant. From Reg. Dev. to Glob. Growth, IBIMA 20151424 (2015).

4. R. Lal, J. Soil Water Conserv. 75, 123A (2020).

5. L. Schreefel, R. P. O. Schulte, I. J. M. de Boer, A. P. Schrijver, és H. H. E. van Zanten, Glob. Food Sec. 26, 100404 (2020).

6. Soekartawi, Realizing Food Independence (Agricultural Research and Development Agency, Jakarta, 2008).

7. D. K. Sadra, Agric. Innov. Dev. 4, 103 (2011).

8. T. SUTAS, The Result Of Inter-Census Agricultural Survey 2018 (BPS-Statistics Indonesia, 2018).

9. W. Akpalu, A. K. Christian, és S. N. A. Codjoe, J. Behav. Exp. Econ. 73, 34 (2018).

10. Statisctics Indonesia, Indonesia in Figure (2019).

11. N. Nurliza, E. Dolorosa, és A. Hamid A. Yusra, Agrar. J. Agribus. Rural Dev. Res. 3, (2017).

12. G. M. H. Deepayan Debnath, Suresh Chandra, Babu Parijat, IFPRI Discuss. Pap. 01635 (2017).

13. Nurhemi, S. R. I. Soekro, és G. S. R., Bank Indones. WP/ 4, 1 (2014).

14. I. Setiawan, J. Geogr. Gea - ejournal.upi.edu (2018).

15. L. Setiartiti, Survey of Main Commodities Contributing to Inflation in Yogyakarta (2011).

16. T. Vinita, Implikasi Letter of Intent Imf Dalam Kebijakan Impor Beras Indonesia ( 2004-2010) (2012).

17. D. T. Armanda, J. B. Guinée, és A. Tukker, Glob. Food Sec. 22, 13 (2019).

18. O. Anwarudin, A. Satria, és A. Fatchiya, Int. J. Progress. Sci. Technol. 10, 218 (2018).

19. J. P. Saragih, J. Ekon. Stud. Pembang. 17, (2016). 
20. Indah Suryawati, Komun. J. 8, (2019).

21. BULOG Annual Report, 2017

22. Law No.18 Year 2012; Concerning of Food 